\title{
Integrated Framework of Load Monitoring by a Combination of Smartphone Applications, Wearables and Point-of-Care Testing Provides Feedback that Allows Individual Responsive Adjustments to Activities of Daily Living
}

\author{
Peter Düking 1,* (D), Silvia Achtzehn ${ }^{2,3}$, Hans-Christer Holmberg ${ }^{4,5}$ and Billy Sperlich ${ }^{1}$ \\ 1 Integrative and Experimental Exercise Science \& Training, Institute for Sport Sciences, \\ University of Würzburg, 97082 Würzburg, Germany; billy.sperlich@uni-wuerzburg.de \\ 2 Institute of Cardiology and Sports Medicine, German Sport University, 50933 Cologne, Germany; \\ achtzehn@dshs-koeln.de \\ 3 The German Research Centre of Elite Sport, German Sport University, 50933 Cologne, Germany \\ 4 School of Sport Sciences, UiT The Arctic University of Norway, 9019 Tromso, Norway; \\ Hans-Christer.Holmberg@miun.se \\ 5 Swedish Winter Sports Research Centre, Department of Health Sciences, Mid Sweden University, \\ SE-831 25 Östersund, Sweden \\ * Correspondence: peter.dueking@uni-wuerzburg.de
}

Received: 20 March 2018; Accepted: 4 May 2018; Published: 19 May 2018

\begin{abstract}
Athletes schedule their training and recovery in periods, often utilizing a pre-defined strategy. To avoid underperformance and/or compromised health, the external load during training should take into account the individual's physiological and perceptual responses. No single variable provides an adequate basis for planning, but continuous monitoring of a combination of several indicators of internal and external load during training, recovery and off-training as well may allow individual responsive adjustments of a training program in an effective manner. From a practical perspective, including that of coaches, monitoring of potential changes in health and performance should ideally be valid, reliable and sensitive, as well as time-efficient, easily applicable, non-fatiguing and as non-invasive as possible. Accordingly, smartphone applications, wearable sensors and point-of-care testing appear to offer a suitable monitoring framework allowing responsive adjustments to exercise prescription. Here, we outline 24-h monitoring of selected parameters by these technologies that (i) allows responsive adjustments of exercise programs, (ii) enhances performance and/or (iii) reduces the risk for overuse, injury and/or illness.
\end{abstract}

Keywords: biofeedback; eHealth; individualized training; injury prevention; IoT; load management; periodization

\section{Introduction}

To optimize performance, athletes schedule their training and recovery in periods, i.e., in micro(e.g., within a single session of training or from day-to-day) or macro-cycles (e.g., on a weekly or monthly basis), with variations in intensity, volume and/or frequency.

Adaptation (e.g., with respect to elevated power output or oxygen uptake) to standardized training varies considerably between individuals [1,2]. Rigid adherence to a standardized or pre-defined program of exercise, without routine monitoring of physiological and perceptual responses and appropriate responsive adjustments, may result in underperformance and/or compromise 
health [3]. The training stimulus becomes inappropriate when the external load (defined here as the work/physical activity completed) is unsuited to the psycho-physiological responses of the individual involved (referred to here as the internal load) [4,5].

Monitoring load is extremely complex, since all of an individual's systems adapt to numerous simultaneous stimuli in an integrated manner. It has been proposed that 24-h monitoring might help take into account the various factors that influence overall adaptation to exercise, thereby improving our insight into the interdependencies in this context between the stress of training, recovery, off-training activities of daily-life, and various other stimuli (e.g., temperature, humidity, psycho-social stressors, and many more) [6] and may allow individual responsive adjustments to exercise programming. From a practical perspective, including that of coaches, monitoring of load designed to detect potential changes in health and performance should be valid, reliable and sensitive, as well as time-efficient, easily applicable, non-fatiguing and as non-invasive as possible [7].

In this context, smartphone applications (Apps), wearable sensors (Wearables) and point-of-caretesting (POCT) all allow (i) high-resolution and/or regular monitoring of a variety of relevant psycho-physiological markers of internal and external load; (ii) minimally or non-invasive collection of data; (iii) rapid evaluation of this data and, thereby, potentially instant (bio-)feedback; (iv) measurements in a variety of different settings (e.g., at home, while training, during competition, while traveling, during daily-living); and/or (v) monitoring without the involvement of sophisticated medical personnel or the necessity for a laboratory [8-10].

Interestingly, despite these considerable advantages, there appears to be little awareness of the capabilities of Apps, Wearables and POCT to provide integrated and instant feedback to athletes and coaches that allows adjustment of exercise to minimize risks to health and optimize adaptation. Accordingly, the present aim was to describe certain approaches of this nature that might be effective.

\section{Monitoring Parameters of External and Internal Load}

The various parameters associated with external and internal training load all appear to be of potential interest in connection with monitoring responses $[4,8,11]$. Here, we focus on external parameters which describe the workload completed by an individual and internal psycho-physiological indicators which can assist coaches in modifying the external load in an appropriate manner. We have focused on load parameters currently monitored by Apps, Wearables, and/or POCT devices by minimally or non-invasive sampling of capillary blood or saliva, since such sampling does not require trained medical personnel. Although certain of their characteristics do overlap, we define Apps as executable software running on a handheld device such as smartphones and, sometimes, smartwatches; Wearables as lightweight devices worn close to, on or in the body that monitor, transmit and/or analyse data, providing bio-feedback [8], while POCT devices allow rapid biochemical, haematological, coagulation or molecular diagnostics at the point-of-care (e.g., the training facility), often in a minimally invasive manner [9].

It is beyond the present scope to consider all possible parameters and those we have chosen to focus on here are listed in Table 1 (external parameters) and Table 2 (internal parameters). While we motivate these choices, we are certainly aware that future technological advancements may well open more sophisticated perspectives.

\section{Monitoring External Parameters}

\subsection{The Duration and Frequency of Training Sessions}

The duration and frequency of exercise sessions, important and simple indicators of external load, can be easily monitored by (sport) watches. Many manufacturers provide the possibility to store this data automatically in a (cloud-based) database, which makes collection, aggregation and visualisation simple and straightforward. 
Table 1. Important external parameters and metrics that can be monitored by Apps and Wearables.

\begin{tabular}{|c|c|c|c|c|}
\hline Type of Parameter & & Individual Parameters & $\begin{array}{l}\text { Method/Sensor } \\
\text { Technology }\end{array}$ & Additional Comments \\
\hline $\begin{array}{l}\text { Duration and frequency } \\
\text { of training sessions }\end{array}$ & & $\begin{array}{l}\text { Time } \\
\text { Number }\end{array}$ & Sport watches & $\begin{array}{l}\text { Sport watches allow automatic } \\
\text { storage of data in the "cloud" }\end{array}$ \\
\hline $\begin{array}{l}\text { Distance covered (in } \\
\text { different speed zones) }\end{array}$ & $\begin{array}{l}\text { e.g., } \\
\text { - } \\
\text { - }\end{array}$ & $\begin{array}{l}\text { absolute value } \\
\text { relative value } \\
\text { acute:chronic workload ratio }\end{array}$ & $\begin{array}{l}\text { Global Navigation Satellite } \\
\text { Systems }\end{array}$ & $\begin{array}{ll}\text { - } & \text { Only useful outdoors } \\
\text { - } & \text { High sampling } \\
\text { frequency required }\end{array}$ \\
\hline Short explosive activities & $\begin{array}{l}\text { e.g., } \\
- \\
-\end{array}$ & $\begin{array}{l}\text { absolute accelerations } \\
\text { relative accelerations }\end{array}$ & Inertial measurement units & $\begin{array}{l}\text { Embedded in a Global } \\
\text { Navigation Satellite System } \\
\text { receiver unit }\end{array}$ \\
\hline Sleep & & $\begin{array}{l}\text { Quantity } \\
\text { Circadian rhythm }\end{array}$ & Actigraphy & $\begin{array}{l}\text { Actigraphy should only be } \\
\text { used with caution to access } \\
\text { sleep quality. }\end{array}$ \\
\hline
\end{tabular}

Table 2. Important internal parameters and metrics that can be monitored by Apps, Wearables and point-of-care-testing.

\begin{tabular}{|c|c|c|}
\hline Type of Parameter & Individual Parameter & Area of Interest \\
\hline \multirow{7}{*}{ General health } & Core, body or skin temperature & Thermoregulation \\
\hline & White blood cell count & Infections \\
\hline & High-sensitive C-reactive Protein & Inflammation \\
\hline & Immunoglobulin A (IglA) & Mucosal immune function \\
\hline & Reactive Oxygen Species & Oxidative stress \\
\hline & Haemoglobin & Anaemia and dehydration \\
\hline & Ferritin & Iron deficiency \\
\hline \multirow{2}{*}{ Bio-psychological stress } & Cortisol & $\begin{array}{ll}- & \text { Protein degradation } \\
- & \text { Suppression of immune function }\end{array}$ \\
\hline & Alpha-amylase & Stress on the sympathetic nervous system \\
\hline Subjective parameters & Questionnaires and diaries & Various psychological aspects \\
\hline \multirow{5}{*}{ Parameters of cardiac stress } & Cardiac troponin & \multirow{3}{*}{ Myocardial stress } \\
\hline & Fatty acid-binding protein & \\
\hline & Heart rate during exercise & \\
\hline & Heart rate variability & Cardiac autonomous nervous system \\
\hline & Heart rate recovery & Overreaching \\
\hline \multirow{4}{*}{ Parameters of muscle damage } & Aspartate aminotransferase & \multirow{4}{*}{$\begin{array}{l}\text { Breakdown of muscle cell } \\
\text { structureProtein catabolism }\end{array}$} \\
\hline & Creatine kinase & \\
\hline & Myoglobin & \\
\hline & Lactate dehydrogenase & \\
\hline \multirow{7}{*}{ Parameters of metabolism } & Lactate & Endurance performance \\
\hline & Urea & Elevated protein catabolism \\
\hline & Uric acid & $\begin{array}{l}\text { Enhanced metabolic strain when muscle } \\
\text { stores of glycogen are depleted }\end{array}$ \\
\hline & Creatinine & Renal functioning \\
\hline & Testosterone & Non-functional overreaching \\
\hline & Tissue oxygenation & Intensity of effort \\
\hline & $\mathrm{pH}$ & Acid-base status \\
\hline
\end{tabular}




\subsection{Distance Covered}

For many athletes the distance covered and time spent in different speed zones (expressed either in absolute or relative terms or as ratios, i.e., the acute/chronic workload ratio $=$ the ratio of the workload during a single week to the average workload during a period of approximately four weeks) allow quantification of the external load and the distance covered exhibits a positive correlation to the likelihood of injury [12-14]. Relatively comfortable Wearable receiver units and Apps assess distance-related parameters employing global navigation satellite systems (GNSS) or local positioning systems (LPS).

\subsection{Short Explosive Activities}

Short explosive activities, such as movements involving a change in direction [15], tackling [16], sprinting [17] or throwing [18], may be utilized as measures of external load. For this purpose, three-dimensional accelerometers and gyroscopes that can be incorporated into various devices monitor parameters of body acceleration that can then be expressed in absolute or relative accumulated terms $(44,40,45)$. For example, since the performance of numerous throws or tackling manoeuvres elevates the risk for injury $[16,18,19]$, short explosive activities should be monitored closely.

\subsection{Environmental Factors}

A variety of environmental factors, including altitude, inclination, slope, temperature, exposure to ultra-violet radiation and humidity $[20,21]$, can all exert a significant impact on external loading. These factors are readily monitored by sensors in Wearables.

\subsection{Sleep}

Developing research regarding sleep in athletes [22] reveals that sleep, performance and/or health are interconnected [23], as would be expected. The length of sleep and its relationship to the circadian rhythm can be estimated from the data supplied by Apps and Wearables employing various procedures $[8,24,25]$.

\subsection{Physical Activity Off-Training}

Periods of off-training are often scheduled in a manner designed to optimize recovery and it is generally accepted that the type of activity (e.g., passive versus active) engaged in after exercise influences this recovery [26] and is therefore important to monitor [27]. Apps [28] and/or Wearables [29] can monitor off-training physical activity with, e.g., accelerometers and/or GPS-receivers and/or by photoplethysmography. Our knowledge concerning how off-training activities affect performance and/or health is presently seriously limited and needs to be extended.

\section{Monitoring Internal Load}

\subsection{Parameters of General Health}

Absence of illness and injury are obviously essential for athletic success. Several (sophisticated) parameters that reflect an athlete's general health, level of stress and immunological status can all be assessed by, Wearables and/or POCT in a minimally or non-invasive manner. For instance, Wearables detect skin and body temperature at rest and during exercise, e.g., to assess heat-induced fatigue, and/or illness, as well as fever [30,31]. Various POCT devices can monitor such health-related variables as the white blood cell count (WBC; including determination of sub-populations and indicative of potential inflection) [32], high-sensitive C-reactive protein (hs-CRP, a marker of inflammation) and salivary immunoglobulin A (SIgA) (an indicator of mucosal immunity) [33]. In addition, POCT can detect toxic reactive oxygen species (ROS) produced during inflammation or exercise [34]. 
The blood level of haemoglobin, a crucial determinant of oxygen delivery, is influenced by the availability of iron and, thus, by the iron-storage protein ferritin. Prolonged and intense exercise is well known to stimulate rapid turn-over of erythrocytes, thereby causing loss of ferritin and a consequent reduction in the concentration of haemoglobin $[35,36]$. Monitoring of ferritin by POCT provides information about the transport of oxygen by the blood, allowing detection, e.g., of premature exhaustion. Furthermore, low levels of haemoglobin may reflect anaemia, whereas elevated levels may be indicative of dehydration.

\subsection{Parameters Related to Cardiac Dynamics and Stress}

With heart rate as a basis, Wearables can provide information on different parameters related to cardiac dynamics and stress $[8,37]$. Heart rate during exercise (expressed relative to an individual's maximum) is often employed to quantify the intensity of exercise and can be used to monitor aerobic adaptation [37]. Variability in the heart rate (defined as the time that elapses between two consecutive R-R intervals) provides insight into the innervation of the heart by the autonomous nervous system [37-39] and appears to be relevant to chronic stress [40]. Such variability can be monitored by Wearables using different technologies [8], as long as potential confounding factors are carefully controlled for [37,41]. Heart rate recovery might indicate overreaching in athletes [42]. In addition, markers of potential myocardial stress, such as troponin and fatty-acid-binding protein (FABP), can be analysed by POCT [43].

\subsection{Parameters Related to Bio-Psychological Stress}

Elevated levels of salivary cortisol and alpha-amylase, both of which can be monitored readily by POCT, are indicative of internal stress [44,45]. This cortisol level increases in response to intense physical exercise. Elevated levels of cortisol, which is considered to be the hormone primarily responsible for catabolic processes, can augment protein degradation, attenuate protein synthesis, and dampen inflammation and immunity $[46,47]$. Alpha-amylase activates the sympathetic nervous system [45] and exhibits diurnal variations, with its level in saliva being more sensitive to exercise-induced stress than that of cortisol [43]. Alpha-amylase also contributes to innate mucosal immunity $[46,48,49]$.

\subsection{Subjective Parameters}

Assessment of subjective psycho-emotional variables [2], including self-reported sleep [50], perceived exertion [51] and general well-being, are crucial components of the monitoring of recovery and stress [11,52]. Although subjective indicators tend to be more sensitive to acute and chronic training loads than objective ones [11], the former can be more easily manipulated to achieve the outcomes desired.

Apps can be programmed to use touch or voice-controlled user-interfaces to monitor various subjective variables in a convenient manner.

\subsection{Neuromuscular Variables}

Applied properly [8], Wearables can detect neuronal activation of muscles that reflects neuromuscular fatigue [53]. POCT can be employed to measure blood levels of, e.g., aspartate aminotransferase, lactate dehydrogenase, creatine kinase, and myoglobin, classical markers of muscular load $[54,55]$, with elevated levels indicating muscle damage and rhabdomyolysis. Since the kinetics of these levels vary, these parameters should be assessed in conjunction with the external load.

\subsection{Parameters Related to Metabolism}

Wearables can measure muscle oxygenation [8], thereby providing an estimate of local oxygen delivery and/or providing insights into muscular responses to exercise [56]. POCT can be utilized 
to measure blood levels of urea, uric acid and creatinine as reflections of metabolic processes. Urea in the capillary blood is indicative of augmented protein catabolism and gluconeogenesis $[57,58]$. An elevated level of uric acid, the terminal product of purine metabolism, is indicative of enhanced metabolism when muscle stores of glycogen have been depleted [55,57]. Creatinine levels provide information concerning renal functioning, which is of particular interest in situations where a proper electrolyte balance is crucial [55]. Levels of lactate can be monitored easily by both POCT devices and Wearables [59] and different lactate thresholds have been utilized as estimates of endurance performance [60].

POCT devices can also measure the partial pressures of oxygen and carbon dioxide in, as well as the $\mathrm{pH}$ of the blood, all important load variables e.g., in connection with hypoxic exposure [43].

POCT-assessed quantification of testosterone in the saliva may allow assessment of non-functional overtraining [46]. Moreover, the ratio of testosterone to cortisol provides further insight into the metabolic state (i.e., catabolic or anabolic) $[43,61]$.

\section{Practical Procedure for Monitoring Relevant Parameters}

Figure 1 illustrates a procedure for individualized management of load and recovery designed to optimize performance and/or minimize the risk of overuse, injury and/or illnesses.

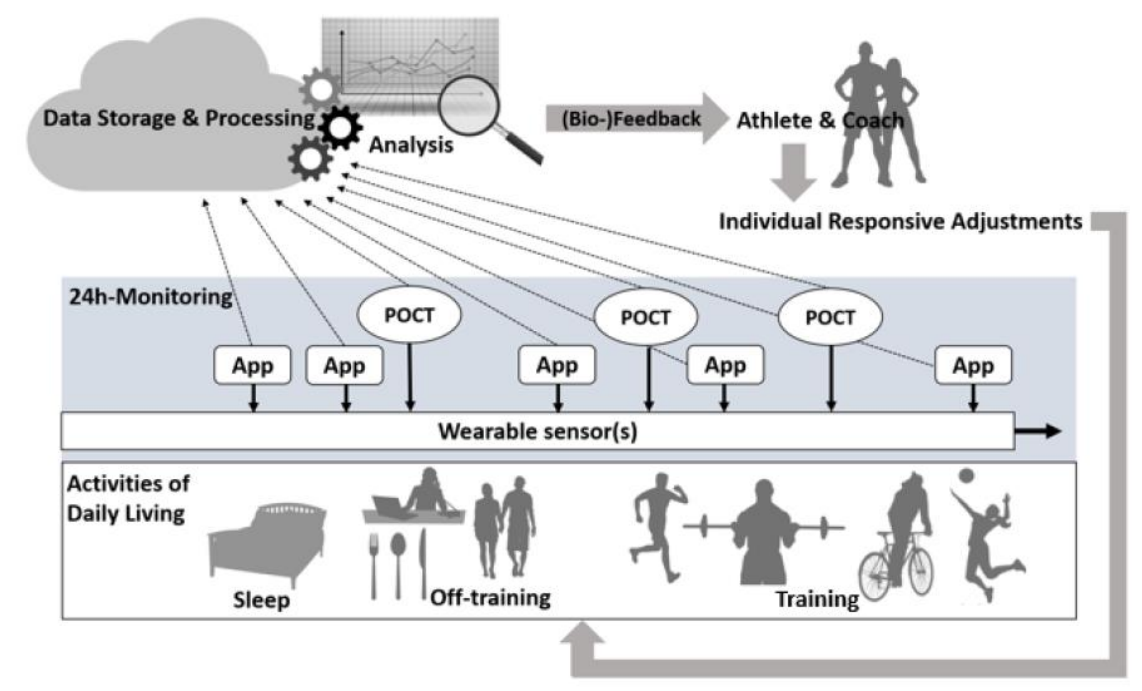

Figure 1. Procedure for monitoring external and internal training load employing Apps, Wearables and POCT and providing feedback to athletes and their coaches that allows beneficial responsive modification of exercise programs.

Wearables allow unobtrusive and continuous monitoring of parameters during training, recovery and periods of off-training [6], as well as, if approved by regulatory bodies [62], during actual competitions.

Apps that collect subjective data and require little compliance may be used selectively per day e.g., in the morning or before or after a training session. Since POCT requires sampling of capillary blood or saliva and the levels measured may show circadian variation, collection of such data daily or at shorter intervals might not be feasible. Since no individual App, Wearable or POCT device on its own can monitor all of the parameters mentioned above, in our opinion a combination of these devices is required in order to achieve a more holistic view of the various physiological, biomechanical and psychological responses of an athlete. It appears advantageous to incorporate at least wearable sensors into a body sensor network which is part of a fully integrated multiplexed sensing system [63], i.e., a central body unit connected wirelessly to various sensor nodes and cloud services that pre-format and synchronize relevant data $[63,64]$, to facilitate user handling of several wearables at the same time. 
The selection of parameters, as well as the timing and frequency of their monitoring clearly depends on the sport involved, the scientific basis for measurement, whether the individual is training or competing, and the extent to which the athlete and his/her coach accept and/or are aware of the benefits and drawbacks of monitoring with Apps, Wearables, and POCT.

It is beyond our present scope to discuss the numerous and rapidly changing technologies and algorithms involved in Apps, Wearables and/or POCT devices and, therefore, we refer practitioners to information concerning the advantages and disadvantages of each $[8,65]$. Currently, there are few reports involving $24-\mathrm{h}$ monitoring in a sports setting $[27,66]$ and more research in this area is clearly warranted.

As the amount of data collected increases, more effective systems for analysis, interpretation and reporting simple, yet meaningful results to athletes and coaches are necessary. With advancements in the analysis of large datasets, suitable algorithms may allow novel insights into the relationships between the parameters monitored and various aspects of performance and/or health. To further improve the framework outlined, we propose that future developments must allow the monitoring of additional parameters non-invasively by Wearables and/or Apps to collect as much data as reliable and as conveniently as possible. Moreover, an easy-to-use system that ideally incorporates all of the parameters mentioned above to provide simple, but powerful feedback to the practitioner is required.

Only if the data collected are stored securely to avoid misuse [67] can the framework outlined be employed successfully by stakeholders.

\section{Practical Considerations}

In this overview we have proposed a procedure for assessing markers of external and internal load by Wearables, Apps and/or POCT in a minimally or non-invasive manner designed to adapt training programs in order to optimize performance and/or minimize the risk of injury and/or illness. However, we have not taken certain other parameters usually monitored by other (invasive) procedures (e.g., venous blood sampling or muscle biopsies) into consideration. Furthermore, we have not discussed the methods and analytical algorithms involved extensively. Since different technologies and algorithms probably provide different results, we advise practitioners to carefully check the reliability and validity of each device of interest carefully following outlined recommendations prior to application in a routine monitoring $[68,69]$ Moreover, when choosing a Wearable, App or POCT device for use, practical considerations such as the costs of the device(s) and of each measurement, as well as the time required for analysis, battery life, options for transfer of data and data security must be taken into consideration.

Finally, we want to emphasize that a framework as suggested here will vary depending on the technology employed, training status, sport and individual goals and most notably the framework does not replace coaching intelligence and the athlete's experience but may assist to enhance performance and/or to reduce the risk of overuse, injury and/or illness.

\section{Conclusions}

Here, we summarize external and internal parameters that can be obtained by Apps, Wearables, and/or POCT and utilized to enhance athletic performance and/or reduce the likelihood of injury and/or illness; we also propose a procedure for such monitoring. For practical purposes, a sophisticated data management system will be required, as well as additional evaluation of the relationships between various parameters and performance and/or health.

Author Contributions: Conceptualization, P.D., S.A. and B.S.; Methodology, P.D., S.A., H-C. H., and B.S.; Writing-Original Draft Preparation, P.D., S.A., B.S.; Writing-Review \& Editing, P.D., S.A., H-C. H., and B.S.; Supervision, P.D. and B.S.; Project Administration, P.D. and B.S..

Funding: This study was funded by the German Research Foundation (DFG) and the University of Wuerzburg in the funding programme Open Access Publishing.

Conflicts of Interest: The authors declare no conflict of interest. 


\section{References}

1. Skinner, J.S.; Wilmore, K.M.; Krasnoff, J.B.; Jaskolski, A.; Jaskolska, A.; Gagnon, J.; Province, M.A.; Leon, A.S.; Rao, D.C.; Wilmore, J.H.; et al. Adaptation to a standardized training program and changes in fitness in a large, heterogeneous population: The HERITAGE Family Study. Med. Sci. Sports Exerc. 2000, 32, $157-161$. [CrossRef] [PubMed]

2. Kiely, J. Periodization Theory: Confronting an Inconvenient Truth. Sports Med. 2018, 48, 753-764. [CrossRef] [PubMed]

3. Soligard, T.; Schwellnus, M.; Alonso, J.M.; Bahr, R.; Clarsen, B.; Dijkstra, H.P.; Gabbett, T.; Gleeson, M.; Hägglund, M.; Hutchinson, M.R. How much is too much? (Part 1) International Olympic Committee consensus statement on load in sport and risk of injury. Br. J. Sports Med. 2016, 50, 1030-1041. [CrossRef] [PubMed]

4. Halson, S.L. Monitoring training load to understand fatigue in athletes. Sports Med. 2014, 44, S139-S147. [CrossRef] [PubMed]

5. Mujika, I. Quantification of Training and Competition Loads in Endurance Sports: Methods and Applications. Int. J. Sports Physiol. Perform. 2017, 12, S2-9-S2-17. [CrossRef] [PubMed]

6. Sperlich, B.; Holmberg, H.C. The Responses of Elite Athletes to Exercise: An All-Day, 24-h Integrative View Is Required! Front. Physiol. 2017, 8, 564. [CrossRef] [PubMed]

7. Starling, L.T.; Lambert, M.I. Monitoring Rugby Players for Fitness and Fatigue: What Do Coaches Want? Int. J. Sports Physiol. Perform. 2017, 15, 1-30. [CrossRef] [PubMed]

8. Düking, P.; Hotho, A.; Holmberg, H.C.; Fuss, F.K.; Sperlich, B. Comparison of non-invasive individual monitoring of the training and health of athletes with commercially available wearable technologies. Front. Physiol. 2016, 7, 71. [CrossRef] [PubMed]

9. Luppa, P.B.; Bietenbeck, A.; Beaudoin, C.; Giannetti, A. Clinically relevant analytical techniques, organizational concepts for application and future perspectives of point-of-care testing. Biotechnol. Adv. 2016, 34, 139-160. [CrossRef] [PubMed]

10. Düking, P.; Holmberg, H.C.; Sperlich, B. Instant biofeedback provided by wearable sensor technology can help to optimize exercise and prevent injury and overuse. Front. Physiol. 2017, 8, 167. [CrossRef] [PubMed]

11. Saw, A.E.; Main, L.C.; Gastin, P.B. Monitoring the athlete training response: Subjective self-reported measures trump commonly used objective measures: A systematic review. Br. J. Sports Med. 2016, 50, 281-291. [CrossRef] [PubMed]

12. Colby, M.J.; Dawson, B.; Heasman, J.; Rogalski, B.; Gabbett, T.J. Accelerometer and GPS-derived running loads and injury risk in elite Australian footballers. J. Strength Cond. Res. 2014, 28, 2244-2252. [CrossRef] [PubMed]

13. Gabbett, T.J. The training-injury prevention paradox: Should athletes be training smarter and harder? Br. J. Sports Med. 2016, 50, 273-280. [CrossRef] [PubMed]

14. Ehrmann, F.E.; Duncan, C.S.; Sindhusake, D.; Franzsen, W.N.; Greene, D.A. GPS and Injury Prevention in Professional Soccer. J. Strength Cond. Res. 2016, 30, 360-367. [CrossRef] [PubMed]

15. Akenhead, R.; French, D.; Thompson, K.G.; Hayes, P.R. The physiological consequences of acceleration during shuttle running. Int. J. Sports Med. 2015, 36, 302-307. [CrossRef] [PubMed]

16. Kelly, D.; Coughlan, G.F.; Green, B.S.; Caulfield, B. Automatic detection of collisions in elite level rugby union using a wearable sensing device. Sports Eng. 2012, 15, 81-92. [CrossRef]

17. Cardinale, M.; Varley, M.C. Wearable Training-Monitoring Technology: Applications, Challenges, and Opportunities. Int. J. Sports Physiol. Perform. 2017, 12, S255-S2629. [CrossRef] [PubMed]

18. Murray, N.B.; Black, G.M.; Whiteley, R.J.; Gahan, P.; Cole, M.H.; Utting, A.; Gabbett, T.J. Automatic Detection of Pitching and Throwing Events in Baseball With Inertial Measurement Sensors. Int. J. Sports Physiol. Perform. 2017, 12, 533-537. [CrossRef] [PubMed]

19. Hendricks, S.; Lambert, M.I. Theoretical Model Describing the Relationship between the Number of Tackles in Which A Player Engages, Tackle Injury Risk and Tackle Performance. J. Sports Sci. Med. 2014, 13, 715-717. [PubMed]

20. Hargreaves, M. Physiological limits to exercise performance in the heat. J. Sci. Med. Sport/Sports Med. Aust. 2008, 11, 66-71. [CrossRef] [PubMed] 
21. Born, D.P.; Hoppe, M.W.; Lindner, N.; Freiwald, J.; Holmberg, H.C.; Sperlich, B. Adaptive mechanisms and behavioural recommendations: Playing football in heat, cold and high altitude conditions. Sportverletzung Sportschaden: Organ der Gesellschaft fur Orthopadisch-Traumatologische Sportmedizin 2014, 28, 17-23. [CrossRef]

22. Taylor, L.; Chrismas, B.C.; Dascombe, B.; Chamari, K.; Fowler, P.M. The Importance of Monitoring Sleep within Adolescent Athletes: Athletic, Academic, and Health Considerations. Front. Physiol. 2016, 7, 101. [CrossRef] [PubMed]

23. Fullagar, H.H.; Skorski, S.; Duffield, R.; Hammes, D.; Coutts, A.J.; Meyer, T. Sleep and athletic performance: The effects of sleep loss on exercise performance, and physiological and cognitive responses to exercise. Sports Med. 2015, 45, 161-186. [CrossRef] [PubMed]

24. Min, Y.H.; Lee, J.W.; Shin, Y.W.; Jo, M.W.; Sohn, G.; Lee, J.H.; Lee, G.; Jung, K.H.; Sung, J.; Ko, B.S.; et al. Daily collection of self-reporting sleep disturbance data via a smartphone app in breast cancer patients receiving chemotherapy: A feasibility study. J. Med. Internet Res. 2014, 16, e135. [CrossRef] [PubMed]

25. Chen, Z.; Lin, M.; Chen, F.; Lane, N.D.; Cardone, G.; Wang, R.; Li, T.; Chen, Y.; Choudhury, T.; Campbel, A.T. Unobtrusive sleep monitoring using smartphones. In Proceedings of the 2013 th International Conference on Pervasive Computing Technologies for Healthcare (PervasiveHealth), Venice, Italy, 5-8 May 2013.

26. Burr, J.F.; Slysz, J.T.; Boulter, M.S.; Warburton, D.E. Influence of Active Recovery on Cardiovascular Function During Ice Hockey. Sports Med. Open 2015, 1, 27. [CrossRef] [PubMed]

27. Sperlich, B.; Becker, M.; Hotho, A.; Wallmann-Sperlich, B.; Sareban, M.; Winkert, K.; Steinacker, J.M.; Treff, G. Sedentary Behavior among National Elite Rowers during Off-Training-A Pilot Study. Front. Physiol. 2017, 8, 655. [CrossRef] [PubMed]

28. DeMasi, O.; Feygin, S.; Dembo, A.; Aguilera, A.; Recht, B. Well-Being Tracking via Smartphone-Measured Activity and Sleep: Cohort Study. JMIR mHealth uHealth 2017, 5, e137. [CrossRef] [PubMed]

29. Wahl, Y.; Düking, P.; Droszez, A.; Wahl, P.; Mester, J. Criterion-Validity of Commercially Available Physical Activity Tracker to Estimate Step Count, Covered Distance and Energy Expenditure during Sports Conditions. Front. Physiol. 2017, 8, 725. [CrossRef] [PubMed]

30. Noakes, T. Fluid replacement during marathon running. Clin. J. Sport Med. 2003, 13, 309-318. [CrossRef] [PubMed]

31. Nakamura, K. Central circuitries for body temperature regulation and fever. Am. J. Physiol. Regul. Integr. Comp. Physiol. 2011, 301, R1207-R1228. [CrossRef] [PubMed]

32. Horn, P.L.; Pyne, D.B.; Hopkins, W.G.; Barnes, C.J. Lower white blood cell counts in elite athletes training for highly aerobic sports. Eur. J. Appl. Physiol. 2010, 110, 925-932. [CrossRef] [PubMed]

33. Born, D.P.; Faiss, R.; Willis, S.J.; Strahler, J.; Millet, G.P.; Holmberg, H.C.; Sperlich, B. Circadian variation of salivary immunoglobin A, alpha-amylase activity and mood in response to repeated double-poling sprints in hypoxia. Eur. J. Appl. Physiol. 2016, 116, 1-10. [CrossRef] [PubMed]

34. Gomes, E.C.; Silva, A.N.; de Oliveira, M.R. Oxidants, antioxidants, and the beneficial roles of exercise-induced production of reactive species. Oxid. Med. Cell. Longev. 2012, 2012, 756132. [CrossRef] [PubMed]

35. Peeling, P.; Dawson, B.; Goodman, C.; Landers, G.; Trinder, D. Athletic induced iron deficiency: New insights into the role of inflammation, cytokines and hormones. Eur. J. Appl. Physiol. 2008, 103, 381-391. [CrossRef] [PubMed]

36. Hinton, P.S. Iron and the endurance athlete. Appl. Physiol. Nutr. Metab. 2014, 39, 1012-1081. [CrossRef] [PubMed]

37. Buchheit, M. Monitoring training status with HR measures: Do all roads lead to Rome? Front. Physiol. 2014, 5, 73. [CrossRef] [PubMed]

38. Aubert, A.E.; Seps, B.; Beckers, F. Heart rate variability in athletes. Sports Med. 2003, 33, 889-919. [CrossRef] [PubMed]

39. Achten, J.; Jeukendrup, A.E. Heart rate monitoring: Applications and limitations. Sports Med. 2003, 33, 517-538. [CrossRef] [PubMed]

40. Dong, J.G. The role of heart rate variability in sports physiology. Exp. Ther. Med. 2016, 11, 1531-1536. [CrossRef] [PubMed]

41. Plews, D.J.; Laursen, P.B.; Le Meur, Y.; Hausswirth, C.; Kilding, A.E.; Buchheit, M. Monitoring training with heart rate-variability: How much compliance is needed for valid assessment? Int. J. Sports Physiol. Perform. 2014, 9, 783-790. [CrossRef] [PubMed] 
42. Le Meur, Y.; Buchheit, M.; Aubry, A.; Coutts, A.J.; Hausswirth, C. Assessing Overreaching with HRR: What is the Minimal Exercise Intensity Required? Int. J. Sports Physiol. Perform. 2017, 12, 569-573. [CrossRef] [PubMed]

43. Achtzehn, S. POCT-Patientennahe Labordiagnostik; Luppa, P.B., Junker, R., Eds.; Springer Verlag: New York, NY, USA, 2017.

44. Dimitriou, L.; Sharp, N.C.; Doherty, M. Circadian effects on the acute responses of salivary cortisol and IgA in well trained swimmers. Br. J. Sports Med. 2002, 36, 260-264. [CrossRef] [PubMed]

45. Rohleder, N.; Nater, U.M. Determinants of salivary alpha-amylase in humans and methodological considerations. Psychoneuroendocrinology 2009, 34, 469-485. [CrossRef] [PubMed]

46. Papacosta, E.; Nassis, G.P. Saliva as a tool for monitoring steroid, peptide and immune markers in sport and exercise science. J. Sci. Med. Sport/Sports Med. Aust. 2011, 14, 424-434. [CrossRef] [PubMed]

47. McLellan, C.P.; Lovell, D.I.; Gass, G.C. Markers of postmatch fatigue in professional Rugby League players. J. Strength Cond. Res./Natl. Strength Cond. Assoc. 2011, 25, 1030-1039. [CrossRef] [PubMed]

48. Koibuchi, E.; Suzuki, Y. Exercise upregulates salivary amylase in humans (Review). Exp. Ther. Med. 2014, 7,773-777. [CrossRef] [PubMed]

49. Nater, U.M.; Rohleder, N.; Schlotz, W.; Ehlert, U.; Kirschbaum, C. Determinants of the diurnal course of salivary alpha-amylase. Psychoneuroendocrinology 2007, 32, 392-401. [CrossRef] [PubMed]

50. Sargent, C.; Lastella, M.; Halson, S.L.; Roach, G.D. The impact of training schedules on the sleep and fatigue of elite athletes. Chronobiol. Int. 2014, 31, 1160-1168. [CrossRef] [PubMed]

51. Foster, C.; Florhaug, J.A.; Franklin, J.; Gottschall, L.; Hrovatin, L.A.; Parker, S.; Doleshal, P.; Dodge, C. A new approach to monitoring exercise training. J. Strength Cond. Res./Natl. Strength Cond. Assoc. 2001, 15, 109-115.

52. Kellmann, M. Preventing overtraining in athletes in high-intensity sports and stress/recovery monitoring. Scand. J. Med. Sci. Sports 2010, 20 (Suppl. 2), 95-102. [CrossRef] [PubMed]

53. Abbiss, C.R.; Laursen, P.B. Models to explain fatigue during prolonged endurance cycling. Sports Med. 2005, 35, 865-898. [CrossRef] [PubMed]

54. Brancaccio, P.; Lippi, G.; Maffulli, N. Biochemical markers of muscular damage. Clin. Chem. Lab. Med. 2010, 48, 757-767. [CrossRef] [PubMed]

55. Banfi, G.; Colombini, A.; Lombardi, G.; Lubkowska, A. Metabolic markers in sports medicine. Adv. Clin. Chem. 2012, 56, 1-54. [PubMed]

56. Born, D.P.; Stoggl, T.; Swaren, M.; Bjorklund, G. Running in Hilly Terrain: NIRS is More Accurate to Monitor Intensity than Heart Rate. Int. J. Sports Physiol. Perform. 2016, 24, 1-21. [CrossRef]

57. Meister, S.; Faude, O.; Ammann, T.; Schnittker, R.; Meyer, T. Indicators for high physical strain and overload in elite football players. Scand. J. Med. Science Sports 2013, 23, 156-1633. [CrossRef] [PubMed]

58. Urhausen, A.; Kindermann, W. Diagnosis of overtraining: What tools do we have? Sports Med. 2002, 32, 95-102. [CrossRef] [PubMed]

59. Borges, N.R.; Driller, M.W. Wearable Lactate Threshold Predicting Device is Valid and Reliable in Runners. J. Strength Cond. Res./Natl. Strength Cond. Assoc. 2016, 30, 2212-2218. [CrossRef] [PubMed]

60. Faude, O.; Kindermann, W.; Meyer, T. Lactate threshold concepts: How valid are they? Sports Med. 2009, 39, 469-490. [CrossRef] [PubMed]

61. Hayes, L.D.; Bickerstaff, G.F.; Baker, J.S. Interactions of cortisol, testosterone, and resistance training: Influence of circadian rhythms. Chronobiol. Int. 2010, 27, 675-705. [CrossRef] [PubMed]

62. Brud, L. Amendments to the Laws of the Game-2015/2016 and Information on the Completed Reform of The International Football Association Board. 2015. Available online: http://resources.fifa.com/ $\mathrm{mm} /$ document/affederation/ifab/02/60/91/38/circular_log_amendments_2015_v1.0_en_neutral.pdf (accessed on 19 February 2017).

63. Gao, W.; Emaminejad, S.; Nyein, H.Y.Y.; Challa, S.; Chen, K.; Peck, A.; Fahad, H.M.; Ota, H.; Shiraki, H.; Kiriya, D.; et al. Fully integrated wearable sensor arrays for multiplexed in situ perspiration analysis. Nature 2016, 529, 509-514. [CrossRef] [PubMed]

64. Kantoch, E.; Augustyniak, P.; Markiewicz, M.; Prusak, D. Monitoring activities of daily living based on wearable wireless body sensor network. Conf. Proc. Eng. Med. Biol. Soc. 2014, 2014, 586-589. [CrossRef]

65. Luppa, P.B.; Proll, G.; Imhoff, M.; Koschinsky, T. Analytische Verfahren, Biosensortechnologie. In POCTPatientennahe Labordiagnostik; Springer: New York, NY, USA, 2017; pp. 39-49. 
66. Rosenberger, M.E.; Buman, M.P.; Haskell, W.L.; McConnell, M.V.; Carstensen, L.L. Twenty-four Hours of Sleep, Sedentary Behavior, and Physical Activity with Nine Wearable Devices. Med. Sci. Sports Exerc. 2016, 48, 457-465. [CrossRef] [PubMed]

67. Austen, K. What could derail the wearables revolution? Nature 2015, 525, 22-24. [CrossRef] [PubMed]

68. Sperlich, B.; Holmberg, H.C. Wearable, yes, but able...?: It is time for evidence-based marketing claims! Br. J. Sports Med. 2017, 51, 1240. [CrossRef] [PubMed]

69. Düking, P.; Fuss, F.K.; Holmberg, H.C.; Sperlich, B. Recommendations for Assessment of the Reliability, Sensitivity, and Validity of Data Provided by Wearable Sensors Designed for Monitoring Physical Activity. JMIR mHealth and uHealth 2018, 6, e102. [CrossRef] [PubMed]

(C) 2018 by the authors. Licensee MDPI, Basel, Switzerland. This article is an open access article distributed under the terms and conditions of the Creative Commons Attribution (CC BY) license (http://creativecommons.org/licenses/by/4.0/). 